\title{
Information Literacy in Nova Scotia: Systematic Mapping of High School Learning Outcomes (Paper)
}

\begin{abstract}
Information literacy has never been more important for the functioning of the democratic process, and for autonomy over one's decisions. The Association for College and Research Libraries (ACRL) created a framework for information literacy, which lists six threshold concepts that an information literate individual possesses. This paper seeks to identify information literacy embedded in the Nova Scotia high school curriculum learning outcomes. Information literacy threshold concepts were mapped in the learning outcomes using qualitative coding. Findings from this study will reveal strengths and weaknesses in IL competencies in the Nova Scotia high school courses. This study also provides recommendation for future research.
\end{abstract}

\section{Introduction}

Matsubayashi \& Freud (2019) conducted a study that found $86 \%$ of Canadian undergraduate students used specific sites, including social media, to find news information, and $40 \%$ of Canadian undergraduate students used search engines, like Google. When using the search engines, Canadians - young adults - often accept the first or second source that populates (Matsubayashi \& Freund, 2019).

Search engines are designed to populate results based on what the algorithm determines you, as a user, will like (Bergstrom \& Bak-Coleman, 2019). Because information is created by everyone and curated by algorithms based on enjoyability, social media sites are a hot spot for misinformation. As Allcott and Gentzkow (2017) contend, most fake news circulation takes place on social media news feeds. This is the case because social media sites are "systematically exploited to manipulate and alter public opinion" (Ferrara, 2017, p. 1).

The most recent case of this in Canada is the Infodemic regarding the Coronavirus pandemic. Over 80\% of Canadian Facebook users admit to having been exposed to at least one form of false information about the Coronavirus since January 2020. Many scholars have suggested promoting information literacy in the public as a possible solution for combatting mis/disinformation (A. Anderson \& Johnston, 2016; J. Anderson \& Rainie, 2020; Austin et al., 2012; Cronin, 2010; Horn \& Veermans, 2019; Kahne \& Bowyer, 2017; Kupiainen et al., 2008; Lähdemäki, 2019; Nold, n.d.; O'Neill, 2010; Rubin, 2020). Odede (2020) explains that information literacy is crucial for developing "skills and abilities necessary for the rapidly changing information environment of the 2020s and beyond" (p. 15). 
The purpose of this research is to systematically map the promotion of information literacy embedded in Nova Scotia high school classes and apply those findings to educational practices, education, and future research in the field of information literacy instruction in Canada. Currently, there is no research mapping information literacy in the Nova Scotia education system. To explore this topic, I seek to answer the following questions:

1. Which Nova Scotia high school courses promote information literacy, as seen in the learning outcomes for each course?

2. What aspects of the ACRL information literacy framework appear more frequently in the Nova Scotia high school learning outcomes?

\section{Methods}

A total of 111 course documents were collected from the Nova Scotia Department of Education and Early Childhood Development's website. There are a total of 164 courses offered between grade 10 and grade 12 in Nova Scotia. Only courses that were designed by the provincial government were included in this study. Learning outcomes from courses in 12 of the province's 16 subject areas were analyzed: arts education, business education and entrepreneurship, career education, English language arts, family studies, learning strategies, mathematics, physical education, science, skilled trades, social studies, and technology education. The breakdown of the number of documents used for the 16 subjects included in this study are as follows: arts education $=15$; business education and entrepreneurship $=7$; career education $=3$; English language arts $=11$; family studies $=7$; learning strategies $=3$; mathematics $=12$; physical education $=6$; science $=17$; skilled trades $=3$, social studies $=14$; and technology education $=$ 12. A breakdown of inclusion/exclusion of courses for all subjects in the Nova Scotia high school curriculum can be found in Table 1 . 
Table 1. Number of courses included in the study based on subject.

\begin{tabular}{|l|c|c|c|}
\hline Subject & $\begin{array}{l}\text { Total } \\
\text { Courses }\end{array}$ & Excluded & $\begin{array}{l}\text { Included in } \\
\text { study }\end{array}$ \\
\hline Mathematics & 13 & 1 & 12 \\
\hline Science & 17 & 0 & 17 \\
\hline English language art & 11 & 0 & 11 \\
\hline Learning Strategies & 3 & 0 & 3 \\
\hline Family Studies & 7 & 0 & 7 \\
\hline Physical Education & 7 & 1 & 6 \\
\hline Technology Education & 14 & 2 & 12 \\
\hline Skilled Trades & 5 & 2 & 14 \\
\hline Social Studies & 17 & 3 & 15 \\
\hline Arts Education & 15 & 0 & 7 \\
\hline Business Education and Entrepreneurship & 8 & 1 & 3 \\
\hline Career Education & 8 & 5 & 0 \\
\hline Advanced Placement & 20 & 20 & 0 \\
\hline Gaelic language & 3 & 3 & 0 \\
\hline International Baccalaureate & 7 & 7 & 0 \\
\hline Core French & 3 & 3 & $\mathbf{1 1 0}$ \\
\hline Other Languages & 6 & 6 & $\mathbf{5 4}$ \\
\hline Total & $\mathbf{1 6 4}$ & & \\
\hline
\end{tabular}

Determining sufficient evidence of information literacy or learning outcomes that are related to information literacy was dependent on keywords such as "analyze," "interpret," "illustrate," and display" and conditional upon whether these verbs related to evidence-based information seeking, introspective writing, thinking, listening, etc. Table 2 provides an example for each threshold concept.

Table 2. Examples of learning outcomes coded to the six ACRL information literacy threshold concepts.

\begin{tabular}{|c|c|c|}
\hline $\begin{array}{l}\text { Threshold } \\
\text { Concept }\end{array}$ & Knowledge Practice & Example from Curriculum \\
\hline $\begin{array}{l}\text { Authority is } \\
\text { constructed } \\
\text { and contextual }\end{array}$ & $\begin{array}{l}\text { Understanding and recognizing different } \\
\text { types of authority and different ways of } \\
\text { displaying authority (formally and } \\
\text { informally); recognizing the importance } \\
\text { of challenging authority, even of scholarly } \\
\text { work; understanding the social dynamics } \\
\text { and connections between and within } \\
\text { information environments; and } \\
\text { identifying one's voice as authoritative } \\
\text { and understanding the impact of their }\end{array}$ & $\begin{array}{l}\text { "articulate their understanding } \\
\text { of ways in which information } \\
\text { texts are constructed for } \\
\text { particular purposes" (NS } \\
\text { English Language Arts 10-12, p. } \\
\text { 18) }\end{array}$ \\
\hline
\end{tabular}




\begin{tabular}{|c|c|c|}
\hline & $\begin{array}{l}\text { participation in information ecosystems } \\
(A C R L, 2015)\end{array}$ & \\
\hline $\begin{array}{l}\text { Information } \\
\text { creation as a } \\
\text { process }\end{array}$ & $\begin{array}{l}\text { Recognition towards information creation } \\
\text { as a process and a responsibility; } \\
\text { understanding one's creation as impactful. } \\
\text { Creators of information recognize that } \\
\text { different information needs require } \\
\text { various information creation processes } \\
(A C R L, 2015)\end{array}$ & $\begin{array}{l}\text { "articulate, advocate, and } \\
\text { justify positions on an issue or } \\
\text { text in a convincing manner, } \\
\text { showing an understanding of a } \\
\text { range of viewpoints" (NS } \\
\text { English Language Arts 10-12, p. } \\
\text { 26) }\end{array}$ \\
\hline $\begin{array}{l}\text { Information } \\
\text { has value }\end{array}$ & $\begin{array}{l}\text { Reference to citation creation, intellectual } \\
\text { property, copyright education, and } \\
\text { reference to open access; understand and } \\
\text { acknowledge the systematic racisms of } \\
\text { marginalized peoples in information } \\
\text { creation and dissemination; make } \\
\text { decisions regarding where to disseminate } \\
\text { and publish information; and continuing } \\
\text { to advocate against issues of privacy and } \\
\text { taking advantage of people's personal } \\
\text { information }(A C R L, 2015)\end{array}$ & $\begin{array}{l}\text { "Consider social, ethical, and } \\
\text { environmental implications of } \\
\text { the findings from their own and } \\
\text { others' investigations" (NS } \\
\text { Science } 10 \text { Guide, p. 2) }\end{array}$ \\
\hline $\begin{array}{l}\text { Research as } \\
\text { inquiry }\end{array}$ & $\begin{array}{l}\text { Create research questions based on } \\
\text { current knowledge; understand how to } \\
\text { limit the scope of the study through } \\
\text { creating simple questions from the main } \\
\text { research question; change research } \\
\text { practices based on the type of research } \\
\text { being conducted; organize, synthesize and } \\
\text { draw meaningful conclusions based on } \\
\text { analysis of information }(A C R L, 2015)\end{array}$ & $\begin{array}{l}\text { "collaboratively and } \\
\text { individually plan, select, and use } \\
\text { appropriate investigation } \\
\text { methods, including fieldwork } \\
\text { and lab experiments, to collect } \\
\text { reliable data (qualitative and } \\
\text { quantitative)" (NS Science } 10 \\
\text { Guide, pg. 1) }\end{array}$ \\
\hline $\begin{array}{l}\text { Scholarship as } \\
\text { conversation }\end{array}$ & $\begin{array}{l}\text { Includes all forms of communication, } \\
\text { whether online, in person, recorded, } \\
\text { written, spoken, etc. at the appropriate } \\
\text { intellect level for the audience; } \\
\text { acknowledging the work of others in } \\
\text { one's work through proper citation; } \\
\text { evaluation of others works and its } \\
\text { contribution to knowledge acquisition } \\
(A C R L, 2015)\end{array}$ & $\begin{array}{l}\text { "Dealing effectively with } \\
\text { different communication } \\
\text { situations including those } \\
\text { addressing unfamiliar } \\
\text { audiences" (NS English } 12 \\
\text { Outcomes, 2019, p.112) }\end{array}$ \\
\hline
\end{tabular}




\begin{tabular}{|l|l|l|}
\hline $\begin{array}{l}\text { Search as } \\
\text { strategic } \\
\text { exploration }\end{array}$ & $\begin{array}{l}\text { Systematically determines the scope, } \\
\text { identifies contributors to specific } \\
\text { information and access their data; } \\
\text { changing search strategy based on the } \\
\text { tools and software presented; and use } \\
\text { divergent and convergent thinking when } \\
\text { retrieving information }(A C R L, 2015)\end{array}$ & $\begin{array}{l}\text { "select text that supports their } \\
\text { learning needs and range of } \\
\text { special interests" (NS English } 12 \\
\text { Outcomes, 2019, p. 113) }\end{array}$ \\
\hline
\end{tabular}

\section{Results}

Table 3 shows how many learning outcomes, in each subject, promotes information literacy. As you see from the figure, more than $75 \%$ show no evidence of information literacy threshold concepts. Moreover, majority of threshold concepts are promoted in less than $10 \%$ of the learning outcomes.

Table 3. Number of learning outcomes related to a threshold concept by subject.

\begin{tabular}{lc}
\hline Subject & Percentage of LO with IL \\
\hline Mathematics & $10.8 \%$ \\
\hline Skilled Trade & $11.1 \%$ \\
\hline Career Education & $14.3 \%$ \\
\hline Family Studies & $15.7 \%$ \\
\hline Physical Education & $17.1 \%$ \\
\hline Technology Education & $19.8 \%$ \\
\hline Learning Strategies & $21.7 \%$ \\
\hline Business Education and Entrepreneurship & $25.5 \%$ \\
\hline Arts Education & $25.6 \%$ \\
\hline Science & $28.9 \%$ \\
\hline Social Studies & $35.7 \%$ \\
\hline English Language Arts & $55.7 \%$
\end{tabular}

Figure 1. Number of learning outcomes related to a threshold concept by subject.

Table 4 shows the number of learning outcomes, by subject, that promote the six different information literacy threshold concepts. As you can see from the figure, research as inquiry is the most common threshold concept. Arts Education and English Language Arts showed higher levels of authority is constructed and contextual, however, research as inquiry remain the second most promoted threshold concept among those two courses. 
Table 4. Share of learning outcomes related to a threshold concept by subject.

\begin{tabular}{lcc}
$\begin{array}{l}\text { ACRL's IL Framework Threshold } \\
\text { Concepts }\end{array}$ & $\begin{array}{l}\text { Number of LO } \\
\text { containing THC }\end{array}$ & $\begin{array}{l}\text { Percentage of LO } \\
\text { containing THC }\end{array}$ \\
\hline Authority is constructed and contextual & 442 & $7.69 \%$ \\
\hline Information creation as a process & 407 & $7.08 \%$ \\
\hline Information has value & 123 & $2.14 \%$ \\
\hline Research as inquiry & 735 & $12.79 \%$ \\
\hline Scholarship as conversation & 353 & $6.14 \%$ \\
\hline Search as strategic exploration & 210 & $3.65 \%$
\end{tabular}

\section{Discussion}

As social media becomes an increasingly important part of the way people retrieve and disseminate information, especially in younger generations, they should be given the opportunity to learn the deceptive nature of social media sites. The information literacy skills necessary for navigating today's information ecosystems should be reflected in education systems across Canada.

If anything, COVID-19 has highlighted the need for information literacy competencies. Most Canadians who interact on social media sites have seen at least one piece of fake news regarding the COVID-19 pandemic (Gruzd \& Mai, 2020). Fake news challenges a government's ability to maintain trust from its citizens. People need to be able to detect falsified or sensationalized information, especially involving health related information.

\section{Limitations}

Learning outcomes in the Nova Scotia high school curriculum were often vague which made it extremely difficult to determine information literacy. Even the learning outcomes that promote information literacy often use vague terminology which requires teachers to interpret the learning outcome with the information literacy framework in mind.

\section{Conclusion}

The absence of information literacy elements in the course learning outcomes should not be interpreted as a failure to adopt this framework, or as a failure to meet some other standard. Embedding information literacy into a curriculum takes time. It takes thorough planning and understanding of the condition of online information ecosystems, the condition in which other countries are meddling with Canadian affairs, and of course, Canadian culture. The learning outcomers were used to guide this research in exploring what $\mathrm{k}$ elements of information literacy are embedded in the curriculum in Nova Scoita. The purpose of this study was to map information literacy threshold concepts to the Nova Scotia secondary learning outcomes created 
by the Department of Education and Early Childhood Development through a ACRL's information literacy lense. Evidence from this study suggests the government should consider examining the curriculum further to understand where information literacy is lacking. 


\section{References}

ACRL. (2015). Framework for information literacy for higher education. ALA.

Anderson, A., \& Johnston, B. (2016). Curriculum Development and the New Curriculum for Information Literacy. In From Information Literacy to Social Epistemology (pp. 83-101). Elsevier. https://doi.org/10.1016/B978-0-08-100545-3.00006-5

Anderson, J., \& Rainie, L. (2020, February 21). Many tech experts say digital disruption will hurt democracy. Pew Research Centre: Internet, Science \& Tech. https://www.pewresearch.org/internet/2020/02/21/many-tech-experts-say-digitaldisruption-will-hurt-democracy/

Austin, E. W., Pinkleton, B. E., Austin, B. W., \& Van de Vord, R. (2012). The relationships of information efficacy and media literacy skills to knowledge and self-efficacy for healthrelated decision making. Journal of American College Health, 60(8), 548-554. https://doi.org/10.1080/07448481.2012.726302

Bergstrom, C. T., \& Bak-Coleman, J. B. (2019). Gerrymandering in social networks. Nature, $573(7772), 40-41$.

Cronin, J. G. R. (2010). Too much information: Why facilitate information and media literacy? International Journal of Humanities \& Arts Computing: A Journal of Digital Humanities, 4(1/2), 151-165. https://doi.org/10.3366/ijhac.2011.0014

Ferrara, E. (2017). Disinformation and social bot operations in the run up to the 2017 French presidential election. First Monday. https://doi.org/10.5210/fm.v22i8.8005

Gruzd, A., \& Mai, P. (2020). The state of social media in Canada 2020 [Data set]. Scholars Portal Dataverse. https://doi.org/10.5683/SP2/XIW8EW 
Horn, S., \& Veermans, K. (2019). Critical thinking efficacy and transfer skills defend against 'fake news' at an international school in Finland. Journal of Research in International Education, 18(1), 23-41. https://doi.org/10.1177/1475240919830003

Kahne, J., \& Bowyer, B. (2017). Educating for democracy in a partisan age: Confronting the challenges of motivated reasoning and misinformation. American Educational Research Journal, 54(1), 3-34. https://doi.org/10.3102/0002831216679817

Kupiainen, R., Sintonen, S., \& Suoranta, J. (2008). Decades of Finnish media education. Finnish Society on Media Education.

Lähdemäki, J. (2019). Case Study: The Finnish National Curriculum 2016-A Co-created National Education Policy. In J. W. Cook (Ed.), Sustainability, Human Well-Being, and the Future of Education (pp. 397-422). Springer International Publishing. https://doi.org/10.1007/978-3-319-78580-6_13

Mai, P. (2020, May 14). [New Survey Report] Inoculating against an Infodemic: A Canada-Wide COVID-19 News, Social Media, and Misinformation Survey| Social Media Lab. https://socialmedialab.ca/2020/05/14/new-survey-report-inoculating-against-aninfodemic-a-canada-wide-covid-19-news-social-media-and-misinformation-survey/ Matsubayashi, M., \& Freund, L. (2019). A comparative study of online news use by young adults in Canada and Japan. Proceedings of the Association for Information Science and Technology, 56(1), 730-732. https://doi.org/10.1002/pra2.152

Nold, H. (n.d.). Using Critical Thinking Teaching Methods to Increase Student Success: An Action Research Project. 16.

O’Neill, B. (2010). Media literacy and communication rights. International Communication Gazette, 72(4-5), 323-338. https://doi.org/10.1177/1748048510362445 
Rubin, V. (2020). Disinformation and misinformation triangle: A conceptual model for "fake news" epidemic, causal factors and interventions. Journal of Documentation, 75(5), $1013-1034$. 